Revista Iberoamericana, Vol. LXIX, Núm. 204, Julio-Septiembre 2003, 613-629

\title{
"LA CASA DE LA PRESENCIA": OCTAVIO PAZ Y SUS LECTURAS CRÍTICAS
}

\author{
POR \\ Antonio Carreño-RodrígueZ \\ Yale University
}

\begin{abstract}
Cada poema implica, de modo implícito o explícito, una poética; cada poética se resuelve en una visión filosófica o religiosa.

Octavio Paz, "Prólogo”. Obras completas I : 19
\end{abstract}

Entre todas las maneras de leer los grandes libros del pasado hay una que prefiero: la que busca en ellos, no lo que somos, sino justamente aquello que niega lo que somos.

Octavio Paz, Los hijos del limo, Obras completas I: $351^{1}$

En la colección de ensayos Hacia una poética radical: ensayos de hermenéutica cultural, el crítico británico William Rowe recurre a la figura mítica de Hermes, el mensajero de los dioses, para dramatizar la comunicación entre el mundo sagrado y el humano. Así, según el crítico, la "hermenéutica, en sus comienzos, era la elucidación de los textos sagrados. Posteriormente, adquirió el sentido de clarificar el mundo mental de un autor para hacer posible que un lector recibiera su mensaje verdadero". Aunque coincidimos con las pretensiones de Rowe al querer mostrar que el interpretante ya no puede producirse como sujeto aislado, y que, por lo tanto, toda lectura está sujeta a un determinado discurso y excluida de otros, pensamos que la alusión irónica a la figura del dios griego como figura de la subjetividad, excluyente y fidedigna (el “mensaje verdadero”), es errónea. La figura de Hermes, como muchos de los mitos clásicos, y como el concepto de verdad según los posmodernos, es indeterminada, compleja, múltiple: plural. Así, pues, Hermes no sólo es el heraldo por excelencia de los dioses, actuando siempre según los deseos de Zeus, sino también es venerado como dios de la elocuencia, de los

\footnotetext{
${ }^{1}$ Las Obras completas de Octavio Paz (México: Fondo de Cultura Económica, 1994) se componen de catorce extensos volúmenes, de los cuales doce están dedicados a la crítica cultural: desde el arte precolombino de México hasta la poética, por ejemplo, de Carlos Fuentes. Citamos la varia obra de Octavio Paz, y de no indicar lo contrario, por las Obras completas que abreviamos con OC. El primer volumen vio la luz en Barcelona (Círculo de Lectores, 1991). En adelante seguimos la segunda edición que sale en México, Fondo de Cultura Económica, 1994.
} 
comerciantes y de los ladrones. Es más, Hermes postula a su vez, el poder del intelecto pervertido, una forma de perversión intelectual, que se encuentra en todos los tipos de estafa, habilidad maliciosa, astucia y tunantería. De esta manera, la observación irónica de Rowe sobre Hermes (24-5) como figura de la recepción de los textos es cuestionable. Hermes: mediador elocuente y astuto entre los dioses y el hombre. O sea, imagen ambigüa y contradictoria; siempre sujeto a un determinado discurso: símbolo perfecto de la actividad exegética.

Se formulan en la actualidad varias tentativas para establecer una teoría científica y definitiva de cómo leer e interpretar las prácticas culturales. Desde el formalismo ruso hasta el estructuralismo francés, todas estas escuelas trataron de elaborar un sistema que enriqueciera el acto hermenéutico. No obstante, en la década de los sesenta, Michel Foucault (1961, 1966), Gilles Deleuze (1962) y Jacques Derrida (1967), cuestionaron (desconstruyeron) los métodos epistemológicos de Occidente, fundados en axiomas como lo "verdadero" y lo "universal”, cuyo origen a su vez emanaba de un concepto de lo "trascendente”. Según estos críticos, a partir de una primera verdad, arbitraria, se formula toda una jerarquía de sentidos que el lector aprehende para descifrar y dar sentido al mundo. Al desconstruir tal logocentrismo platónico (basado en un sistema de oposiciones y distinciones binarias), ${ }^{2}$ Derrida y Foucault revelaron que tal método no sólo reducía las posibilidades heterogéneas del sentido a dicotomías estáticas, sino que también ocultaba las estructuras que preservaban las relaciones jerárquicas que establece la diferencia. De este modo, la noción que proponen es que los discursos no están formulados sobre una positividad única, más bien, sobre una natura mutable, contingente, relativa y siempre parcial. Es más, la autoridad es siempre de carácter provisional; nunca trascendente. Los críticos Colin Lankshear y Peter L. McLaren (1993) resumieron de una manera tajante estas ideas fundamentales para el pensamiento posestructuralista:

The real is not transparent to the world; the real and the concept are insurmountably asymmetrical. Truth has no real name other than meanings rhetorically or discursively assigned to it. Discourses may in fact possess the power of truth, but in reality they are historically contingent rather than inscribed by natural law; they emerge out of social conventions. In this view, any discourse of conducting is bounded by historical, cultural, and political conditions and the epistemological resources available to articulate its meaning. Educators involved in critical research remind us that people do not possess power but produce it and are produced by it in their relational constitution through discourse. (382)

Teniendo en cuenta estas reflexiones, nuestra lectura sobre la obra crítica de Octavio Paz, sigue tales postulados. Es decir: sin una actividad exegética, las prácticas culturales no tienen sentido; el receptor en lugar de ejercer una subjetividad excluyente y, supuestamente fidedigna, está socialmente inmerso en su entorno. Por lo tanto, quien lee

2 "Those terms that are pre-eminent and invensted with truth, achieve that status by excluding and marginalising what they are not. [...] One term, in its discursive and material operation, represents the centre; the excluded term is the margin: active/passive, culture/nature, hard/soft, masculine/ feminine, etc.” (Mercer 21). 
es partícipe de determinados diálogos, y al ser excluido de otros, inmerso en una determinada tradición, funde pasado y presente; y finalmente, las determinadas legitimaciones y deslegitimaciones a las cuales está sujeto un interpretante surgen en parte de la recepción y, en parte, de las instituciones y de los espacios discursivos, tanto sociales como culturales. Aquí se sitúa todo estudio metacrítico, cuyo objetivo es mostrar las convenciones de una lectura.

\section{EL ESPACIO CRÍTICO LATINOAMERICANO O EL NO MAN’S LAND}

Una de las características fundamentales del discurso crítico latinoamericano y, en general, de la llamada crítica periférica o del tercer mundo, es la incorporación de las teorías diversas en un mismo espacio discursivo. Dicha práctica, a modo de "canibalismo teórico”, combina con frecuencia los principios teóricos (a veces opuestos) de Roman Jakobson con los de Jacques Derrida, o los de Michel Foucault con los de Jacques Lacan. Y esto sucede tanto entre los intelectuales “orgánicos” (a la manera sartriana) como entre los pensadores institucionales. De esta manera, son escasas las tentativas por parte de la crítica latinoamericana de formular una teoría propia o metodología para analizar las prácticas culturales. En un capítulo titulado "Sobre la crítica”, incluido en Corriente alterna (1967), Octavio Paz observa:

Pero carecemos [los latinoamericanos] de un "cuerpo de doctrina" o doctrinas, es decir, de ese mundo de ideas que, al desplegarse, crea un espacio intelectual: el ámbito de una obra, la resonancia que la prolonga o la contradice. [...] Si se pasa de la crítica como creación a la crítica como alimento intelectual, la escasez se vuelve pobreza. [...] Por último, si se pasa a la crítica literaria propiamente dicha, la pobreza se convierte en miseria. Ese espacio al que me he referido y que es el resultado de la acción crítica, lugar de unión y de confrontación de las obras, entre nosotros es un no man’s land. (39-41)

No obstante, quizá la excepción a la regla sea la amplia obra crítica del propio Paz. Sus extensas como heterogéneas lecturas parecen abarcar, a primera vista, materias de índole dispersa: desde el arte precolombino de su país hasta el cine poético/filosófico de Luis Buñuel, y desde el Baghavad Gita hasta Un Coup de dés de Mallarmé. No obstante $\mathrm{y}$, a medida que se va leyendo la rica amalgama de escritos culturales, el archilector se percatará que, como ocurre en toda lectura, el corpus crítico de Paz está claramente sujeto a un determinado discurso, lo fijan unas determinadas convenciones cuya génesis se establece ya en sus primeros textos. En la primera edición de El arco y la lira (1956) y, principalmente, en el capítulo “Los signos en rotación” (1965), incorporado como epílogo a la segunda edición de este libro (1967), Paz analiza la función del significante en la lírica: la meditación poética que cuestiona qué es un poema y cómo funciona. Con los ensayos, explica Paz, "no he querido justificar a mi poesía, defenderla o explicarla. Los escribí por una necesidad a un tiempo intelectual y vital; quise dilucidar, para mí y para otros, la naturaleza de la vocación poética y la función de la poesía en las sociedades” (OC., I, 16). De forma paralela, en Los hijos del limo (1974), Paz "recoge y desarrolla el tema final de 
El arco y la lira: las relaciones entre poesía e historia” (OC., I, 26). ${ }^{3}$ Es decir, a través de diversas lecturas, Paz establece una historiografía de la poesía moderna occidental. Configura su hermenéutica preguntándose: ¿qué significa un poema? Estos dos libros, y algunos artículos sobre poetas en concreto (Quevedo, Huidobro, Darío, Pessoa y Cernuda) nos ayudarán a responder a la pregunta que venimos anticipando desde el inicio de este ensayo: ¿qué discurso o tradición fundamenta la obra crítica de Octavio Paz?

Ya desde el siglo XVIII, los estudios literarios se han valorado como la tarea propia de una pequeña élite intelectual, reservada sólo para los académicos. En las primeras décadas de nuestro siglo, observa el mismo fenómeno el crítico británico F. R. Leavis, en un panfleto de 1930, titulado Mass Civilization and Minority Culture:

In any period it is upon a small minority that the discerning appreciation of art and literature depends: it is (apart from cases of the simple and familiar) only a few who are capable of unprompted, first-hand judgement. They are still a small minority, though a larger one, who are capable of endorsing such first-hand judgement by genuine personal response...The minority capable not only of appreciating Dante, Shakespeare, Baudelaire, Hardy (to take major instances) but of recognising their latest successors constitute the consciousness of the race (or of a branch of it) at a given time...Upon this minority depends our power of profiting by the finest human experience of the past; they keep alive the subtlest and most perishable parts of tradition. Upon them depend the implicit standards that order the finer living of an age, the sense that this is the direction in which to go. In their keeping...is the language, the changing idiom upon which fineliving depends, and without which distinction of spirit is thwarted and incoherent. By "culture" I mean the use of such language. (citado en Easthope 3-4)

Este pensamiento sigue aún vigente pese a que los llamados 'estudios culturales' (creados ellos mismos desde la propia academia anglo-americana) intenten cuestionar la validez y la hegemonía impuesta por la academia misma. No obstante, si comparamos, por ejemplo, los organismos discursivos de los países periféricos con las instituciones angloamericanas (escribimos este trabajo desde una universidad norteamericana de prestigio y de gran tradición crítica), encontramos que en la periferia existe un mayor porcentaje de intelectuales llamados 'universales' (o ‘sartrianos') con igual derecho a ejercer lecturas sobre las prácticas culturales. Los más distinguidos de esta nueva especie (se inician en Francia con Victor Hugo) se convierten en figuras públicas e incluso políticas. Sus posturas son emblemáticas del esfuerzo intelectual de su país en el extranjero: Borges, García Márquez, Vargas Llosa, y, como no, Octavio Paz. ${ }^{4}$ Este derecho privilegiado de

\footnotetext{
${ }^{3}$ Los hijos del limo (1974) es el libro más extenso e importante que, con posterioridad a El arco y la lira, dedicó Paz a la evolución de la lírica contemporánea desde el Romanticismo. Surge a partir de las Charles Eliot Norton Lectures dictadas en el curso 1971-1972 en la Universidad de Harvard. Por otra parte, somos conscientes de que pasan más de quince años entre estos dos libros, y más de treinta entre el primero y el "Prólogo" a las Obras completas. Aunque es imposible hablar de sólo un Paz-crítico y de sólo un Paz-poeta, no tenemos más remedio que acudir a esta atemporalización, pese a que ésta no excluye la continuidad y coherencia de su pensamiento crítico.

${ }^{4}$ Es curioso notar que la canonización de estos escritores (este poder) y de sus obras se suelen lograr previamente desde el extranjero. Posteriormente, se consagran en su país natal. Este hecho es
} 
opinar, fruto de las múltiples redes de poder socio-culturales, es otorgado por diversas instituciones pedagógicas (desde la Academia Sueca hasta los programas didácticos de la $\mathrm{TV}$ ), por el pueblo y por el escritor mismo. Es cierto que a estos personajes públicos siempre les envuelve un claro elemento de auto-mitificación. Paz, que no es immune a esta postura narcisista, declara en el "Prólogo" a sus Obras Completas:

[...] surgía una [pregunta] que me atañía particularmente: ¿cuál era mi lugar como poeta hispanoamericano, en la tradición poética de Occidente? Esa pregunta se extendía a todos los poetas hisoanoamericanos y, en general, a la cultura y la historia de nuestros pueblos. Dos extremos de la misma preocupación: el tema de la peculiar relación de América Latina con Europa, especialmente con España y Portugal, era (y es) para mí inseparable de la otra cuestión: el lugar de la poesía hispanoamericana en la tradición poética de Occidente. Todos los poetas hispanoamericanos han decidido conquistar y asimilar a la tradición europea; todos también han intentado no tanto separarse de ella como transformarla en algo nuevo y radicalmente diferente. Las dos preguntas, una acerca de la filiación histórica de nuestros pueblos y otra sobre nuestra poesía, no eran de orden teórico o general sino personal. Sólo si respondía a ellas podía justificar mi existencia, como poeta y como ser humano. (1994, I, 25)

El Paz-poeta se inserta dentro de un campo literario al sentirse miembro de "una tradición [poética] que comenzó con la lengua española” (OC., I, 16). ${ }^{5}$ Difícil sería para 'uno de afuera' el oponerse al derecho que siente en establecerse en este discurso. No obstante (y ahora volvemos al Paz-crítico), su conciencia de escribir como un poeta consagrado anticipa de una manera sorprendente (recordemos que escribe Los hijos del limo en 1966) la crítica posmodernista: "Mis puntos de vista son de un poeta hispanoamericano; no son una disertación desinteresada, sino una exploración de mis orígenes y una tentativa de autodefinición indirecta. Estas reflexiones pertenecen a ese género que Baudelaire llamaba crítica parcial, la única que le parecía válida” (OC., I, 358). Por otra parte, al igual que su modelo Baudelaire, Paz escribe para un círculo reducido de lectores: estudiosos y académicos que querrán profundizar sobre su obra y biografía, o para aquéllos que simplemente se interesan en un discurso como testimonio de un período artístico e histórico; o para artistas e intelectuales que miran desde el "afuera" de la consagración y que aspiran a formar parte de tal culto; o para lectores interesados en apoderarse de una cierta “cultura general” a pesar de que, según él, escribe para sí mismo. Obviamente, no son estos los únicos lectores de la obra crítica de Octavio Paz pues, como venimos exponiendo, toda lectura y escritura (dentro de los llamados 'estudios literarios') forman parte de una infinita red de comunicaciones y de discursos desde donde se ejercen las relaciones del poder.

característico de los países periféricos. Sobre esto Paz expresa en "Sobre la crítica” (Corriente alterna 42): "[...] para que una obra sea considerada entre nosotros debe contar antes con la bendición de Londres, Nueva York o París”.

${ }^{5}$ Utilizaremos las apelaciones 'Paz-poeta’ y ‘Paz-crítico’ para facilitar la comprensión del ensayo. No obstante, somos conscientes que esta distinción es arbitraria y que ambos discursos no sólo son plurales (existen múltiples poetas) sino que también se entrelazan y se sostienen mutuamente. 
Para Octavio Paz, el elemento que separa las artes de los artefactos es el estilo. Según advierte en El arco y la lira, el estilo es el punto de partida de todo intento creador. En el interior de un estilo es posible descubrir lo que separa a un poema de un tratado en verso, a un cuadro de una lámina educativa, a un mueble de una escultura. Ese elemento distintivo es la poesía. Sólo la poesía puede mostrar la diferencia entre creación y estilo, entre la obra de arte y el utensilio. “La poesía convierte la piedra, el color, la palabra y el sonido en imágenes. Y esta segunda nota, el ser imágenes, y el extraño poder que tienen para suscitar en el oyente o en el espectador constelaciones de imágenes, vuelve poemas todas las obras de arte" (OC., I, 49).

Como vemos, Paz utiliza en un sentido amplio la palabra poesía y la define como la memoria de los pueblos. El poema, por lo tanto, no es simplemente una forma literaria sino el lugar de encuentro entre la poesía y el hombre; un organismo verbal que contiene, suscita o emite poesía. Forma y sustancia son lo mismo (OC., I, 42). Esta concepción de la unidad, que el crítico otorga al poema, se enraíza en la larga tradición iniciada ya por Aristóteles en su Poética al definir la tragedia como "una acción esforzada y completa...” y, posteriormente desarrollada en el Renacimiento donde se establece la unidad de tiempo, lugar y acción para finalmente ser reformulada en el Romanticismo como una unidad orgánica. El hilo conductor que otorga la supuesta unidad a estas imágenes dispersas es para Paz, la imaginación:

El poema posee una innegable unidad de tono, ritmo y temperatura. Es un todo. O los fragmentos, vivos aún, todavía resplandecientes, de un todo. Mas la unidad del poema no es de orden físico o material; tono, temperatura, ritmo e imágenes poseen unidad porque el poema es una obra. Y la obra, toda obra, es el fruto de una voluntad que transforma y somete la materia bruja a sus designios. (OC., I, 166)

Paz es, pues, heredero directo de la tradición crítica de Coleridge quien proponía que el poema "propos[es] to itself such delight from the whole, as is comparable with a distinct gratification from each component part" (Easthope 22); es decir, una totalidad cerrada sobre sí misma, una frase o un conjunto de frases que forman un todo. Ésta es para nuestro crítico la principal virtud que separa el poema de los otros géneros literarios:

\footnotetext{
Mientras el poema se presenta como un orden cerrado, la prosa tiende a manifestarse como una construcción abierta y lineal. Valéry ha comparado la prosa con la marcha y la poesía con la danza. Relato o discurso, historia o demonstración, la prosa es un desfile, una verdadera teoría de ideas o hechos. La figura geométrica que simboliza la prosa es la línea: recta, sinuosa, espiral, zigzagueante, mas siempre hacia adelante y con una meta precisa. De ahí que los arquetipos de la prosa sean el discurso y el relato, la especulación y la historia. El poema, por el contrario, se ofrece como un círculo o una esfera: algo que se cierra sobre sí mismo, universo autosuficiente y en el cual el fin es también un principio que vuelve, se repite y se recrea. (OC., I, 90)
}

De esta manera, libros como Los cantos de Maldoror de Lautréamont, Alicia en el país de las maravillas de Lewis Carrol, o "El jardín de los senderos que se bifurcan” de Borges son poemas. "En ellos la prosa se niega a sí misma; las frases no se suceden 
obedeciendo al orden conceptual o al del relato, sino presididas por las leyes de la imagen y el ritmo. Hay un flujo y reflujo de imágenes, acentos y pausas, señal inequívoca de la poesía” (OC., I, 92). El sentido del poema, por lo tanto, no es otro que el poema mismo. Sus imágenes son irreductibles a cualquier explicación o interpretación. Porque, según Paz, "hay muchas maneras de decir la misma cosa en prosa; sólo hay una en poesía” (OC., I, 124). ${ }^{6}$

La inspiración también juega un papel fundamental en la poética de Paz. Según éste, la poesía es una gracia que desciende sobre el poeta: un misterio. Consiste en un hablar los dioses por boca humana: "el poeta es un médium por cuyo intermedio se expresan, en cifra, el Sexo, el Clima, la Historia o algún otro sucedáneo de los antiguos dioses y demonios” (OC., I, 170). Si para los antiguos la inspiración era un misterio (Platón decía que el poeta era un poseído), para los modernos es también un problema ya que "contradice nuestras concepciones psicológicas y nuestra misma idea del mundo’ (OC., I, 167). De nuevo, el crítico se apoya en las concepciones poéticas del siglo XIx (particularmente en la filosofía de Novalis y Baudelaire) para describir y teorizar sobre el acto poético, ya que el poeta "es, al mismo tiempo, el objeto y el sujeto de la creación poética: es la oreja que escucha y la mano que escribe lo que dicta su propia voz" (OC., I, 172). Es una especie de mago y sacerdote a la vez. Por una parte (poeta magus) ${ }^{7}$ el nombre y el ser en la poesía son lo mismo y, por otra, el poeta tiene el poder de restablecer la palabra original, preBabélica. Poesía es, según Paz, la comunión entre los dioses y el hombre.

Una de las funciones de la poesía (“quizá la más primordial”, de acuerdo con Paz), es la transfiguración del pasado en presencia viva. Este tiempo/no tiempo mítico sólo se establece merced a una concepción romántica de la analogía universal: "El ritmo poético no deja de ofrecer analogías con el tiempo mítico; la imagen con el decir místico; la participación con la alquimia mágica y la comunión religiosa” (OC., I, 131) ${ }^{8}$ El poeta, por

\footnotetext{
${ }^{6}$ La aserción ontológica de que el poema es una unidad con esencia propia es un concepto habitual dentro de los discursos literarios, sobre todo a partir de los formalistas rusos y de los New Critics. Así en Northrop Frye: 'the provisional hypothesis which we must adopt for the study of every poem is that the poem is unity'; Michael Riffaterre, 'the characteristic feature of the poem is its unity'; F.D. Hirsch, 'the literary text has 'coherence' y I.A. Richards: "it is never what a poem says which matters, but what it is".

7 "La operación poética no es diversa del conjuro, el hechizo y otros procedimientos de la magia. Y la actitud del poeta es muy semejante a la del mago. Los dos utilizan el principio de la analogía” (OC, I, 76).

${ }^{8}$ El concepto que tiene Paz de la analogía universal es obviamente baudelairiano. Comparemos a ambos: El poeta francés en su famoso soneto Correspondance escribe: "La Nature est un temple où de vivants piliers / Laissent parfois sortir de confuses paroles; / L'homme y passe à travers des forêts de symboles / Qui l'observent avec des regards familiers. // Comme de longs échos qui de loin se confondent / Dans une ténébreuse et profonde unité, / Vaste comme la nuit et comme la clarté, / Les parfums, les couleurs et les sons se répondent. // Il est de parfums frais comme des chairs d'enfants, / Douce comme les hautbois, verts comme les praries, / -Et d'autres, corrompus, riches et triomphes, // Ayant l'expanion des choses infinies, / Comme l'ambre, le musc, le benjoin et l'encens / Qui chantent les transports de l'esprit et des sens”. Y Paz: "El lenguaje, como el universo, es un mundo de llamadas y respuestas; flujo y reflujo, unión y separación, inspiración y espiración. Unas palabras se atraen, otras se repelan y todas se corresponden. El habla es un conjunto de seres vivos, movidos
} 
lo tanto, es transmisor del ritmo universal. Actualiza "ese pasado que es un futuro que es un presente” (OC., I, 87). Las palabras del poeta son a la vez suyas y ajenas. Por una parte, son históricas, fechables; pertenecen a un pueblo y a un momento de su habla. Por otra, son anteriores a toda fecha: un comienzo absoluto. Es decir, como “toda creación humana, el poema es un producto histórico, hijo de un tiempo y un lugar; pero también es algo que trasciende lo histórico y se sitúa en un tiempo anterior a toda historia, en el principio del principio. Antes de la historia, pero no fuera de ella" (OC., I, 191).$^{9}$ Y es que la poesía sin dejar de estar compuesta de imágenes hechas de palabras, trasciende el lenguaje y la historia, en tanto que sistema dado de significaciones históricas:

La imagen hace perder a las palabras su movilidad e intercanjeabilidad. Los vocablos se vuelven insustituibles, irreparables. Han dejado de ser instrumentos. El lenguaje cesa de ser un útil. El regreso del lenguaje a su naturaleza original, que parecía ser el fin último de la imagen, no es así sino el paso preliminar para una operación aún más radical: el lenguaje, tocado por la poesía, cesa de pronto de ser lenguaje. O sea: conjunto de signos móviles y significantes. El poema trasciende el lenguaje. [...] [E]l poema es lenguaje y lenguaje antes de ser sometido a la mutilación de la prosa o la conversación-, pero es algo más también. Y ese algo más es inexplicable por el lenguaje, aunque sólo puede ser alcanzado por él. Nacido de la palabra, el poema desemboca en algo que la traspasa. [...] La experiencia poética es irreductible a la palabra y, no obstante, sólo la palabra la expresa. (El arco y la lira, OC., I, 124-25)

De acuerdo con el crítico Anthony Easthope (23), los estudios literarios asimilan el célebre principio de Pascal (Pensées... 684) de que todo autor busca un sentido en el cual los pasajes contradictorios queden ser reconciliados. Una filosofía similar (aunque más compleja) la plantea Paz cuando escribe: "la pluralidad de lo real se manifiesta o expresa como unidad última, sin que cada elemento pierda su singularidad esencial. Las plumas son piedras, sin dejar de ser plumas. [...] El decir poético dice lo indecible” (OC., I, 125). Dos extremos: el poema abarca todos los significados; es el significado de todas las significaciones y, simultáneamente, le niega toda significación al lenguaje. ${ }^{10}$

por ritmos semejantes a los que rigen a los astros y las plantas" (OC., I, 75). Y de nuevo, "El universo deja de ser un vasto almacén de cosas heterogéneas. Astros, zapatos, lágrimas, locomotoras, sauces, mujeres, diccionarios, todo es una inmensa familia, todo se comunica y se transforma sin cesar [...]" (OC., I, 126).

${ }^{9}$ No sólo la poesía tiene este carácter trascendente: "El carácter irrepetible del poema lo comparten otras obras: cuadros, esculturas, sonatas, danzas, monumentos". Y continúa, "por otra parte, la piedra de la estatua, el rojo del cuadro, la palabra del poema, no son pura y simplemente piedra, color, palabra: encarnan algo que los trasciende y traspasa” (OC., I, 45-49).

${ }^{10}$ Conviene señalar que el contacto que tuvo Paz con la filosofía oriental fue de enorme influencia sobre esta teoría de la reconciliación de los opuestos. Los siguientes pasajes de El arco y la lira y de Recapitulaciones (citamos ambos por OC, I) constatan, respectivamente, dicha propuesta: "Cualquiera que sea el desenlace de su aventura, lo cierto es que, desde este ángulo, la historia de Occidente puede verse como la historia de un error, un extravío, en el doble sentido de la palabra: nos hemos alejado de nosotros mismos al perdernos en el mundo. Hay que empezar de nuevo. El pensamiento oriental no ha padecido este horror a lo 'otro', a lo que es y no es al mismo tiempo. El mundo occidental es el del 'esto o aquello'; el oriental, el del 'esto y aquello', y aun el de 'esto es 


\title{
LECTURA VIRTUAL, LECTURA HISTÓRICA
}

Pero el poema no sólo es una realidad verbal. Según el crítico mexicano, también es un acto. La composición sólo constituye una parte de la obra poética. Según Paz, el poema acabado es simplemente una posibilidad. Sólo se anima (se convierte en 'poesía') a través del contacto con un lector u oyente. O sea, el poema requiere la participación. Así, pues, "la lectura, repite el gesto del poeta: la lectura es una traducción que convierte al poema del poeta en el poema del lector” (OC., I, 396). Cada lector, según Paz, es otro poeta; y cada lectura, otro poema:

\begin{abstract}
El autor es el primer lector de su poema y con su lectura se inicia una serie de interpretaciones y reacciones. Cada lectura produce un poema distinto. Ninguna lectura es definitiva y, en este sentido, cada lectura, sin excluir a la del autor, es un accidente del texto. Soberanía del texto sobre su autor-lector y sus lectores sucesivos. El texto permanece, resiste a los cambios de cada lectura. Resiste a la historia. Al mismo tiempo, el texto sólo se realiza en esos cambios. El poema es una virtualidad transhistórica que se actualiza en la historia, en la lectura. No hay poema en sí, sino en mí o en ti. Vaivén entre lo transhistórico y lo histórico: el texto es la condición de las lecturas y las lecturas realizan al texto, lo insertan en el transcurrir. (OC., I, 472)
\end{abstract}

De nuevo reaparece la identidad de los contrarios (pre-Parménides) que ya vimos en referencia a la significación/no significación del lenguaje poético (véase la nota 11). No obstante, aquí la reconciliación de opuestos establece una referencia con la historicidad y con la transhistoricidad de la lectura. El texto es siempre el mismo y en cada lectura es distinto. Para Paz, la lectura de un texto poético es histórica y es lo que niega a la historia en el momento en que la afirma.

Cada lectura es una experiencia fechada que niega a la historia con el texto y que a través de esa negación se inserta de nuevo en la historia. Variación y repetición: la lectura es una interpretación, una variación del texto y en esa variación el texto se realiza, se repite -y absorbe la variación” [...] Leer un texto no-poético es comprenderlo, apropiarse de su sentido; leer un texto poético es resucitarlo, re-producirlo. (OC., I, 473)

aquello’”. Ya en el más antiguo Upanishad se afirma sin reticencias el principio de identidad de los contrarios: “Tú eres mujer. Tú eres hombre. Tú eres el muchacho y también la doncella...”. Y estas afirmaciones las condensa el Upanishad Chandgya en la célebre fórmula: “Tú eres aquello”. Toda la historia del pensamiento oriental parte de esta antiquísima aseveración, del mismo modo que la de Occidente arranca de la de Parménides. Éste es el tema constante de especulación de los grandes filósofos budistas y de los exégetas del hinduismo. El taoísmo muestra las mismas tendencias. Todas estas doctrinas reiteran que la oposición entre esto y aquello es, simultáneamente, relativa y necesaria, pero que hay un momento en que cesa la enemistad entre los términos que nos parecían excluyentes" (118). "Lo que propone el budismo es el fin de las relaciones, la abolición de las dialécticas- un silencio que no es disolución sino la resolución del lenguaje” (296). Para profundizar más sobre este tema, véase el interesante estudio de Emir Rodríguez Monegal (35-46). Por otra parte, nos parecen interesantes estos dos pasajes en cuanto a que anticipan los estudios post-coloniales y los discursos sobre la construcción de las identidades. 
Una vez reproducido el texto, la próxima tarea del crítico es intentar darle un sentido hermenéutico. En la colección de aforismos titulada "Recapitulaciones” (1967) (OC, I, 293), Paz afirma que el poema “es inexplicable, no ininteligible”. La misión de la crítica "no es tanto trasmitir informaciones como filtrarlas, trasmutarlas y ordenarlas. La crítica opera por negaciones y por asociaciones: define, aísla y, después, relaciona” (Corriente alterna 44). Relaciona las obras elegidas para posteriormente “descubrir [la] posición [de cada obra] dentro del conjunto y de acuerdo con las predisposiciones y tendencias de cada una” (Corriente alterna 41). Al reconocer lo literario como construcción, Paz establece un concepto que dará en premisa de la crítica postestructuralista.

La crítica es lo que constituye eso que llamamos una literatura y que no es tanto la suma de las obras como el sistema de sus relaciones: un campo de afinidades y oposiciones. [...] En este sentido, la crítica tiene una función creadora: inventa una literatura (una perspectiva, un orden) a partir de las obras. (Corriente alterna, 40-1)

Tal premisa anticipa y, en cierto modo, justifica el libro más importante que Paz dedicará a partir de El arco y la lira a la evolución de la poesía contemporánea: Los hijos del limo, cuya primera edición sale dos años después, en 1974. En este libro, Paz no sólo intenta descubrir el lugar de la poesía hispanoamericana en la tradición poética de Occidente, sino que a su vez propone un orden (léase crítica) a lo que la crítica cultural apelará 'modernidad' ${ }^{11}$ Veamos esta segunda cuestión: ¿qué es la modernidad para Paz? y, sobre todo, ¿qué papel desempeña la poesía dentro de este movimiento?

Desde Descartes el concepto humano de la realidad exterior se ha transformado radicalmente. "La ruptura de la analogía es el comienzo de la subjetividad. El hombre entra en escena, desaloja a la divinidad y se enfrenta a la no significación del mundo" (OC, I, 311). A partir de Kant, tal es el subjetivismo moderno: la existencia del mundo exterior solamente a partir de nuestra conciencia.

Una y otra vez esa conciencia se postula como una conciencia trascendental y una y otra vez se enfrenta al solipsismo. La conciencia no puede salir de sí y fundar el mundo. Mientras tanto, la naturaleza se nos ha convertido en un mundo de objetos y relaciones. Dios ha desaparecido de nuestras perspectivas vitales y las nociones de objeto, substancia y causa han entrado en crisis. Ahí donde el idealismo no ha destruido la realidad exterior -por ejemplo, en la esfera de la ciencia- la ha convertido en un objeto, en un "campo de experiencias” y así la ha despojado de sus antiguos atributos” (OC, I, 168-69). ${ }^{12}$

Desaparecido el mundo de valores cristianos - cuyo centro es, justamente, la analogía universal o la correspondencia entre cielo, tierra e infierno- no le queda nada al hombre, excepto la asociación fortuita y casual de pensamientos e imágenes: un lenguaje cuyo

${ }^{11}$ Los hijos del limo es un texto básico ya que contribuye al establecimiento de un campo de estudio importante dentro de la literatura occidental: la poesía latinoamericana contemporánea. A su vez, colabora en la fundación de sus textos canónicos.

12 "La modernidad se inicia cuando la conciencia de la oposición entre Dios y ser, razón y revelación, se muestra como realmente insoluble. A la inversa de lo que ocurrió en el Islam, entre nosotros la razón crece a expensas de la divinidad” (OC, I, 353). 
sentido, en vez de estar regido por un ritmo cósmico o espiritual, se gobierna por el azar $(O C, \mathrm{I}, 98)$. El lenguaje, por lo tanto, es simbólico: trata de poner en relación dos realidades heterogéneas: el hombre y las cosas que nombra. Tal carencia de sentido entre el hombre y el mundo se manifiesta de manera explícita en El Quijote: "La desarmonía entre el hidalgo manchego y su mundo no se resuelve, como en la épica tradicional, por el triunfo de uno de los principios sino por su fusión. Esa fusión es el humor, la ironía. La ironía y el humor son la gran invención del espíritu moderno” (OC, I, 224). Ironía y humor conllevan la conciencia de una ausencia.

Según Paz, la idea de modernidad es un concepto exclusivamente occidental ya que sólo podía nacer dentro de nuestra concepción del tiempo: un tiempo sucesivo e irreversible. La modernidad nace como una crítica de la eternidad cristiana. ${ }^{13} \mathrm{Y}$ es que "todas las otras civilizaciones postulan imágenes y arquetipos temporales de los que es imposible deducir, inclusive como negación, nuestra idea del tiempo” (OC., I, 352).$^{14} \mathrm{La}$ época ‘moderna' (período que se inicia en el siglo XVIII) ${ }^{15}$ niega el arquetipo cristiano, pero a su vez afirma la negación de todas las ideas que se habían hecho los hombres del tiempo. O sea, se convierte así en la primera era que exalta el cambio y lo convierte en su fundamento.

En el dominio de las artes, la conciencia moderna, de acuerdo con Paz, se convierte en crítica. Al cambiar nuestro concepto del tiempo, el hombre moderno tuvo conciencia de pertenecer a una cierta tradición, lo que equivale a decir que se vio distinto a ella. Este hecho separa al hombre moderno del tradicionalista. Éste vive inmerso en un pasado sin interrogarlo; "más que tener conciencia de sus tradiciones, viven con ellas y en ellas" (OC, I, 339). No obstante, el sentirse sujeto a una tradición lleva, tarde o temprano, el interrogarla y, a veces, el negarla. Así, por primera vez en la historia, el hombre es consciente de su historicidad: la tradición moderna es una expresión de nuestra conciencia histórica:

13 "La doble herencia del monoteísmo judaico y de la filosofía pagana constituyen la dicotomía cristiana. La idea griega del ser-en cualquiera de sus versiones, de los presocráticos a los epicúreos, estoicos y neoplatónicos- es irreductible a la idea judaica de un Dios único, personal y creador del universo. Esta oposición fue el tema central de la filosofía cristiana desde los Padres de la Iglesia. Una oposición que la escolástica intentó resolver con una ontología de una sutileza extraordinaria. La modernidad es la consecuencia de esa contradicción y, en cierto modo, su resolución en sentido opuesto al de la escolástica (OC, I, 353).

${ }^{14}$ Paz continúa, "la vacuidad budista, el ser sin accidentes ni atributos del hindú, el tiempo cíclico del griego, el chino y el azteca, o el pasado arquetípico del primitivo, son concepciones que no tienen relación con nuestra idea del tiempo" (OC, I, 352).

15 'La expresión 'poesía moderna' se usa generalmente en dos sentidos, uno restringido y otro amplio. En el primero, alude al período que se inicia con el simbolismo y que culmina en la vanguardia. La mayoría de los críticos piensan que este período comienza con Charles Baudelaire. Algunos añaden otros nombres, como el de Edgar Allan Poe o el de Nerval de Les Chimères. En el sentido amplio, tal como se ha usado en este libro, la poesía moderna nace con los primeros románticos y sus predecesores inmediatos de finales del siglo xVIII, atraviesa el siglo XIX y, a través de sucesivas mutaciones que son asimismo reiteraciones, llega hasta el siglo xx. Se trata de un movimiento que comprende a todos los países de Occidente, del mundo eslavo al hispanoamericano, pero que en cada uno de sus momentos se concentra y manifiesta en dos o tres puntos de irradiación" (OC, I, 436). 
Por una parte, es una crítica del pasado, una crítica de la tradición; por la otra, es una tentativa, repetida una y otra vez a lo largo de los dos últimos siglos, por fundar una tradición en el único principio inmune a la crítica, ya que se confunde con ella misma: el cambio, la historia. (OC, I, 339)

Nuestra modernidad se distingue de las de otras épocas, según Paz, no por su celebración de lo nuevo y sorprendente, aunque también eso influye, sino por ser una ruptura. La era moderna es una "crítica del pasado inmediato, interrupción de la continuidad". En el arte, el proceso se acelera de una manera tan asombrosa que "lo moderno" no sólo es hijo de una edad crítica sino que también es crítico de sí mismo. El arte es 'moderno', de acuerdo con Paz, porque es crítico: “desde su nacimiento el arte moderno, fue un arte crítico; su realismo, teñido de pasión, no fue tanto un retrato como una crítica de la realidad” (OC., I, 314). Y es que el principio que funda el tiempo moderno ya no es una verdad eterna, sino la verdad del cambio. Si en el pasado, la crítica tenía por objeto llegar a la verdad ahora, en la edad moderna, la verdad es crítica. Esta actitud se despliega en dos direcciones contradictorias: como "una negación del tiempo lineal de la modernidad” y como “una negación de sí mismo. Por lo primero, negaba la modernidad; por lo segundo, la afirmaba” (OC., I, 463). Tal pensamiento se manifiesta tanto en lo político como en lo artístico: como crítica de la historia y de la misma poesía. Si en todas las sociedades existía la contradicción entre historia y poesía, sólo en la edad moderna se manifiesta de manera explícita. La poesía moderna ha sido la crítica del mundo moderno tanto como la crítica de sí misma. De este modo,

[la] analogía e ironía enfrentan al poeta con el racionalismo y el progresismo de la era moderna pero también, y con la misma violencia, lo oponen al cristianismo. El tema de la poesía moderna es doble: por una parte es un diálogo contradictorio con y contra las revoluciones modernas y las religionas cristianas; por la otra, en el interior de la poesía y de cada obra poética, es un diálogo entre analogía e ironía. (Los hijos del limo, OC., I, 326)

El "primer diálogo" es, pues, un enfrentamiento entre la poesía y la religión. Es lógico. La religión es la forma que tiene la poesía de encarnarse y hacerse rito e historia. Al cuestionar la historia y el rito por primera vez, el hombre moderno, perdido (caído) sale en busca del principio anterior a la historia; la revelación de la primera palabra fundacional: la poesía. Y es que la poesía propone encontrar una equivalencia (la metáfora) en la que no desaparezca ni las cosas en su particularidad concreta, ni el hombre en su individualidad. ${ }^{16}$ Así, se proclama como "un principio rival del espíritu crítico y como el único que puede sustituir los antiguos principios sagrados” (OC., I, 230-1). El "segundo diálogo" es la necesidad que experimentan los poetas modernos para reflexionar e inclinarse sobre la

16 "La escritura automática es un método para alcanzar un estado de perfecta coincidencia entre las cosas, el hombre y el lenguaje; si ese estado se alcanzase, consistiría en una abolición de la distancia entre el lenguaje y las cosas y entre el primero y el hombre. Pero esa distancia es la que engendra el lenguaje; si la distancia desaparece, el lenguaje se evapora. O dicho de otro modo: el estado al que aspira la escritura automática no es la palabra sino el silencio” (OC, I, 241). 
creación poética, para arrancarle su secreto. Según Paz, se trata de una crítica que se resuelve en imagen. De ahí, que una de las características más sobresalientes de la poesía moderna sea su esencia metacrítica. Desde Hölderlin a Mallarmé la poesía construye transparentes monumentos de su propia caída. Ese descenso se detiene en la negación de la no significación del mundo y en su posterior transformación en significado. ${ }^{17}$ Esta es, según Paz, la historia de la literatura moderna. Podría formularla a modo de "novela de caballería: Las hazañas de la subjetividad o la conquista del mundo por la negación del mundo" (OC., I, 311).

\section{LAS METONIMIAS DE LA HISTORIA}

Para ilustrar la unidad de la poesía moderna, Paz escoge los episodios más prominentes de su historia: su nacimiento con los románticos ingleses y alemanes, sus metamorfosis en el simbolismo francés y el modernismo hispanoamericano, su culminación y fin en las vanguardias del siglo xx. Es decir, después de haber definido la modernidad y analizado sus características más sobresalientes, Paz inserta dentro de su discurso a los poetas y a los poemas que más le convienen para sostener su teoría literaria. Evidentemente, mientras algunos escritores entran dentro del relato de la poesía moderna (Baudelaire, Darío, Huidobro, o el propio Paz), otros son excluidos (Lamartine, Musset o Vigny, por ejemplo). ${ }^{18}$ No podría ser de otra forma: la poesía, para ser moderna tiene que representar una empresa autónoma y a contra-corriente. Es decir, de ninguna forma podría sostener el statu quo. ${ }^{19}$ Para que esto se cumpla, y para que forme parte de la categoría histórica

${ }^{17}$ Así, se expresa Paz sobre el poema “Altazor” de Huidobro, el iniciador de la poesía moderna en nuestra lengua, según el crítico: "El ser ha devorado al significado [en Altazor]. Para Huidobro la operación poética consiste en la fusión entre el significado y el ser. Extraña confusión: el lenguaje regresa al ser pero deja de ser lenguaje. Operación de divinización consecuente con el programa creacionista: el poeta crea como la naturaleza y como Dios [...]. La crítica ha concluido dictaminando: la aventura de Huidobro termina en abolición del significado y, por lo tanto, del lenguaje: una derrota. Sin embargo, para el poeta chileno cada una de las palabras o pseudopalabras que dice Altazor (o el pájaro tralalí) es un objeto vivo y que, por serlo, ha dejado de significar. El lenguaje del canto final de Altazor ha alcanzado la dignidad suprema: la del pleno ser" [...]. El viaje por el unipacio y el espaverso de Huidobro es la historia de la ascensión del sentido al ser. Al final el pájaro tralalí emite unas sílabas; no es una música sino un lenguaje más allá de sentido y sinsentido”. Los últimos versos de Altazor no dicen, rigurosamente, nada. Recuerdan a las invocaciones de los gnósticos que tanto irritaban a Plotino. La nada es la otra cara del ser” (OC, III, 1994:182-84).

${ }^{18}$ Para Paz el 'verdadero' Romanticismo francés es distinto del de los manuales. "Hay dos: uno, el de los manuales e historias de la literatura, está compuesto por una serie de obras elocuentes, sentimentales y discursivas que ilustran los nombres de Musset y Lamartine; otro, que para mí es el verdadero, está formado por un grupo muy reducido de obras y de autores: Nerval, Nodier, el Hugo del período final y los llamados "pequeños románticos". En realidad, los verdaderos herederos del romanticismo alemán e inglés son los poetas posteriores a los románticos oficiales, de Baudelaire a los simbolistas. Desde esta perspectiva, Nerval y Nodier hacen figura de precursores y Hugo aparece como un contemporáneo” (OC I, 391).

19 "Cada movimiento artístico negaba al precedente, y a través de cada una de estas negociaciones el arte se perpetuaba. Sólo dentro del tiempo lineal la negación podía desplegarse plenamente y sólo en una edad crítica como la nuestra la crítica podía ser creadora” (Los hijos del limo, OC I: 463). 
que Paz propone, debe cumplir las características que venimos señalando: una cierta beligerancia frente a la religión, y sobre todo, una oposición consciente al tiempo mítico cristiano; una voluntad poética de crear un nuevo espacio de lo sagrado; una reacción frente, hacia y en contra de la modernidad: la Ilustración, la razón crítica, el liberalismo, el positivismo y el marxismo y, finalmente, una teorización de la poesía dentro de la poesía misma: su metacrítica. ${ }^{20}$ Veamos algunos ejemplos. Para Paz, Baudelaire se considera un poeta moderno, y no lo es tanto por la ruptura con el orden cristiano como por la conciencia de esa ruptura (OC, I, 97). Así, pues, la modernidad es conciencia. Por lo tanto, Dante, inconsciente de tal separación, según las características que establece Paz, no es considerado moderno: "la conciencia de la culpa es asimismo nostalgia, conciencia del exilio. Pero Dante no necesita probar sus afirmaciones, y su palabra sostiene sin fatiga, como el tallo a la fruta, el significado espiritual: no hay ruptura entre palabra y sentido” (OC, I, 97). Por otra parte, la novedad de Rubén Darío y del movimiento modernista consistió en "la invención de metros; su originalidad, en la resurrección del ritmo acentual” (Cuadrivio 26). Sin embargo, en el ensayo de "El caracol y la sirena”, Paz se detiene en los conceptos de amor presentes en Rubén Darío; ideas a modo de "corrientes en la alquimia sexual del taoísmo y en el tantrismo budista e hindú, nunca habían aparecido con tal violencia en la poesía castellana, toda ella impregnada de cristianismo” -y en la corriente de ocultismo que atraviesa la obra del poeta (Cuadrivio 57). ${ }^{21}$ En el ensayo “La palabra edificante,” que versa sobre la poesía de Luis Cernuda, manifiesta de manera concluyente los criterios indispensables para ser consagrado ‘poeta moderno'.22 Según Paz, Cernuda es “uno de los poquísimos moralistas que ha dado España, en el sentido en que Nietzsche es el gran moralista de Europa moderna y, como él decía, “su primer psicólogo” (Cuadrivio 169). Y como el filósofo alemán, la poesía de Cernuda no cesa nunca de atacar los valores y creencias de la sociedad. Es una poesía anti-establishment, anti-statu quo:

\footnotetext{
${ }^{20}$ En el artículo "El desconocido de sí mismo”, cuyo análisis se ofrecerá a continuación, Paz dice lo siguiente acerca de la meditación poética: "A la reflexión poética debemos algunos de los textos cardinales de la poesía moderna de Occidente, poemas en los que nuestra historia simultáneamente se asume y se consume: negación de sí misma y de los significados tradicionales, tentativa por fundar otro significado" (Cuadrivio 185).

${ }^{21}$ Más adelante, Paz afirma: "La crítica universitaria generalmente ha preferido cerrar los ojos ante la corriente de ocultismo que atraviesa la obra de Darío. Este silencio daña la comprensión de su poesía. Se trata de una corriente central y que constituye no sólo un sistema de pensamiento sino de asociaciones poéticas”. Y continúa, “el terror de la muerte, el horror de ser, el asco de sí mismo, expresiones que aparecen una y otra vez a partir de Cantos de vida y esperanza, son ideas y sentimientos de raíz cristiana; pero falta la otra mitad, la escatología del cristianismo”. De nuevo, "el sentimiento de la mancha original impregna mucho de sus mejores poemas: ignorancia de nuestro origen y de nuestro fin, miedo ante el abismo interior, horror de vivir a tientas". Finalmente, "en el Poema del otoño, una de sus grandes y últimas composiciones, se unen los dos ríos que alimentan su poesía: la meditación ante la muerte y el erotismo panteísta” (Cuadrivio 60-63).

${ }^{22}$ Nos parecen relevantes las palabras con las cuales Paz inicia el ensayo por lo que muestran la 'selectividad' sujetiva de nuestro crítico: “No me propongo, en las notas que siguen, recorrer la obra de Cernuda en su totalidad. Escribo sin tener a la mano sus libros más importantes y, fuera de lo que haya dejado en mi memoria un trato de años con sus escritos, no poseo sino unos cuantos poemas en una antología, la tercera edición de Ocnos y Desolación de la Quimera” (Cuadrivio 170).
} 
en [su poesía, la] destrucción y creación son inseparables, pues aquello que afirma implica la disolución de lo que la sociedad tiene por justo, sagrado o inmutable. Como la de Pessoa, su obra es una subversión y su fecundidad espiritual consiste, precisamente, en que pone a prueba los sistemas de la moral colectiva, tanto los fundados en la autoridad de la tradición como los que nos proponen los reformadores sociales. Su hostilidad ante el cristianismo no es menor que su repugnancia ante las utopías políticas [...]. (Cuadrivio 169)

Paralelamente, Paz afirma que Cernuda descubre el espíritu moderno a través del surrealismo y, sobre todo, merced a las obras de Pierre Reverdy. Es en este periodo inicial al que, según Paz, le debemos a Cernuda las “blasfemias más hermosas”. Sin embargo, la experiencia del surrealismo en Cernuda no fue igual, por ejemplo a la de Neruda, García Lorca o Villaurrutia. Para Cernuda, el movimiento iniciado por Breton fue algo más que una simple poética o una escuela de asociaciones e imágenes verbales: "fue una tentativa de encarnación de la poesía en la vida, una subversión que acabara tanto al lenguaje como a las instituciones” (Cuadrivio 175). Según Paz, Cernuda fue el primero y casi el único (Paz se autoincluye dentro de esa misma tradición) fiel al instinto crítico. Es esta una característica que distingue a los grandes poetas en la tradición de Nerval, Baudelaire y Mallarmé, ya que Cernuda comprendió e hizo suya "la verdadera significación del surrealismo como movimiento de liberación -no del verso sino de la conciencia: el último gran sacudimiento espiritual de Occidente” (Cuadrivio 175). A su vez, la lírica de Cernuda se distingue por su meditación sobre la poesía misma. Representa la conciencia del lenguaje, la metacrítica, pues para Cernuda "la poesía tenía por objeto conocerse a sí mismo pero, con la misma intensidad, fue una tentativa por crear su propia imagen” (Cuadrivio 186). En resumen, Paz considera la obra de Cernuda como uno de los testimonios más impresionantes del hombre moderno. Según éste, La realidad y el deseo es el mito del poeta moderno, descendiente directo de los poètes maudits, ya que la obra manifiesta explícitamente la condenación del hombre a la soledad promiscua. El hombre ‘moderno’ se halla sin salida, encarcelado en una prisión del tamaño del planeta. Su única tarea sobre la tierra es la de "crear obras, hacer vida del tiempo muerto, dar significado al transcurrir ciego” (Cuadrivio 202). Cernuda, concluye, es el poeta 'moderno' par excellence.

Pero el arte moderno no se establece simplemente por un corte cronológico. Los criterios de Paz no son tan ingenuos. Quevedo, por ejemplo, en su poema "Lágrimas de un penitente”, escribe el único poema moderno de la literatura española hasta Rubén Darío. Y es que "la modernidad de Quevedo no está en su admirable retórica, como creía Borges, sino en su dramática conciencia de la caída y en la imposibilidad del rescate” ("Prólogo", OC, I, 23). Esta verdadera y gozosa conciencia en el mal de cierta manera anticipa la obra de Baudelaire y de los poetas modernos: El "estoicismo [cristiano] de Quevedo se transformará en la edad moderna [...] en angustia, miedo, ruptura, blasfemia, rebeldía y a veces, muy pocas como en Eliot, en reconciliación” ("Prólogo”, OC, I, 23). En un artículo titulado "Heráclito y algunos sonetos" (Sombras de obras, 1983), Paz analiza el famoso soneto de Quevedo, “Amor constante más allá de la muerte”. El poema es “un ejemplo extraordinario de la cristalización del deseo en idea fija”. De nuevo, a Paz 
le interesa destacar cómo el poeta barroco "afirma una suerte de blasfema obstinación ante la muerte"; se aparta del platonismo y del petrarquismo; no afirma la inmortalidad del alma sino la del cuerpo y, finalmente, observa cómo la resurrección del cuerpo en los dos últimos versos es "escandalosa para un cristiano: el agente de la resurrección no es Dios sino el amor humano hacia otra criatura humana” (131). Aunque Paz reconoce que Quevedo “no es un autor sino muchos”, a él no le cautivan los poemas eróticos o satíricos. No son modernos. No tienen por tema la conciencia de la caída y, por lo tanto, carecen de una actitud negativa ante el mundo y la vida.

Como sujeto que comunica, el crítico no tiene más remedio que acudir a la palabra, al discurso para describir otro discurso. Para el interpretante, por lo tanto, no existe un lugar imparcial (sin palabras) desde donde pueda juzgar un texto: imposible un afuera que mire hacia un dentro. Lo mismo sucede en el espacio de los estudios literarios. La literatura no es una esencia eterna, universal (interior al texto), indiferente ante toda lectura. Más bien, su valor se otorga a consecuencia de un discurso construido: de un proceso o una práctica de lectura entre el texto y el contexto (Easthope 33). Históricamente, este proceso no se ha podido separar de la existencia del campo literario: "universo autónomo provisto de principios específicos de evaluación de prácticas y obras” (Rowe, 32). ${ }^{23}$ Los primeros discursos críticos de Octavio Paz no son ajenos a este proceso. Sus ideas sobre la literatura, de la poesía sobre todo, y la función que ésta desempeña dentro de la sociedad, así como su poética y hermenéutica, están claramente circunscritas a su tiempo y a sus necesidades coyunturales. No obstante, la crítica de Paz se valora como una respuesta más, una de las múltiples verdades dadas al fenómeno de la creación poética. También entra en juego dentro de esa infinita red de discursos que constituye la actividad exegética de las prácticas culturales. Es el propio Paz, el que demuestra a varios niveles, en el presente y, desde el presente, cómo toda lectura cambia de acuerdo con el contexto en que se ubica: “Además, el gusto y el juicio -las dos armas de la crítica-cambian con los años y aun con las horas: aborrecemos en la noche lo que amamos por la mañana” (OC., I, 1990, 15). Cuán lejos ya del Octavio Paz que escribió El arco y la lira , en 1957.

\section{BiBLIOGRAFÍA}

Borges, Jorge Luis. “El jardín de los senderos que se bifurcan”. Ficciones. Madrid: Alianza Editorial, 1971.

Carroll, Lewis. Alicia en el país de las maravillas. Barcelona: Editorial Juventud, 10 ed., 2000.

Chevalier, Jean y Alain Gheerbrant. Diccionario de los símbolos. Barcelona: Editorial Herder, 1986.

Derrida, Jacques. De la Grammatologie. Paris: Les Editions de Minuit, 1967.

Easthope, Anthony. Literary into Cultural Studies. London/New York: Routledge, 1991. Foucault, Michel. Les mots et les choses. Paris: Gallimard, 1966.

Jakobson, Roman. Questions de poétique. Paris: Éditions de Seuil, 1973.

23 “[El] campo literario [...] se constituye a medida que establece su autonomía, es decir, sus leyes específicas de funcionamiento, dentro del campo del poder” (Rowe 32). 
Lacan, Jacques. Écrits. Paris: Éditions de Seuil, 1966.

Lankshear, Colin y Peter L. McLaren (Eds.). Critical Literacy: Politics, Praxis, and the Postmodern. Albany: State University of New York Press, 1993.

Lautréamont, comte de. Los cantos de Maldoror. Montevideo: Centro editor de América Latina, 1969.

Mercer, Kobena. "Welcome to the Jungle: Identity and Diversity in Postmodern Politics”. Identity, Community, Culture, Difference. Jonathan Rutherford, ed. London: Lawrence and Wishart, 1990.

Pascal, Blaise. "Pensées”. The Provincial Letters. New York: The Modern Library, 1941. Paz, Octavio. La casa de la presencia: poesía e historia. Obras completas I. $4^{\mathrm{a}}$ ed. México: Fondo de Cultura Económica, 1994.

Fundación y disidencia. Obras completas III. $4^{\mathrm{a}}$ ed. México: Fondo de Cultura Económica, 1994.

Corriente alterna. [1967]. México: Siglo Veintiuno, 1972.

Cuadrivio. México: Editorial Joaquín Mortiz, 1969.

Rodríguez Monegal, Emir. "Relectura de El arco y la lira”. Revista Iberoamericana 74 (1971): 35-46.

Rowe, William. Hacia una poética radical: ensayos de hermenéutica cultural. Lima: Mosca Azul, 1993. 